\title{
Casaubon's Ghosts: The Haunting of Legal Scholarship
}

Allan C. Hutchinson

Osgoode Hall Law School of York University, ahutchinson@osgoode.yorku.ca

Source Publication:

Legal Studies. Volume 21, Issue 1 (2001), p. 65-98.

Follow this and additional works at: https://digitalcommons.osgoode.yorku.ca/scholarly_works c) (i) $\ominus$

This work is licensed under a Creative Commons Attribution-Noncommercial-No Derivative Works 4.0 License.

\section{Recommended Citation}

Hutchinson, Allan C. "Casaubon's Ghosts: The Haunting of Legal Scholarship." Legal Studies 21.1 (2001): 65-98.

This Article is brought to you for free and open access by the Faculty Scholarship at Osgoode Digital Commons. It has been accepted for inclusion in Articles \& Book Chapters by an authorized administrator of Osgoode Digital Commons. 


\title{
Technically the King Can Do Wrong in Reorganizing Insolvent Corporations: Evidence from Canada*
}

\author{
Stephanie Ben-Ishai \\ Assistant Professor, Osgoode Hall Law School at York University, Canada
}

\section{Abstract}

Taken together the international move from liquidation to reorganization-based bankruptcy regimes and the international move to abolish Crown priority in bankruptcy provide Canada with an opportunity to rethink Crown priority in bankruptcy. This paper makes the case that abolishing Crown priority in bankruptcy in Canada is optimal given a revaluation of traditional normative claims surrounding Crown priority in the context of a bankruptcy system that favours reorganization when possible. While this paper focuses on Canada, it engages in a normative assessment that may be useful for possible reforms to Crown priority in the United States and in other jurisdictions that, like Canada, have been influenced, not only by the English model, but also by the American bankruptcy and reorganization system.

\footnotetext{
* This paper was originally presented at the INSOL Academics' Group Meeting in Cape Town, SA, April 2^4, 2004. The author is grateful for the comments provided at the INSOL Academics' Group Meeting in Cape Town and by Professor Iain Ramsay and Professor Poonam Puri on an earlier draft of this paper. The excellent research assistance provided by Jenny Siu (Osgoode Hall Law School, Class of 2005), Jen Oosterbaan (Osgoode Hall Law School, Class of 2006), and Melissa Ewert (Osgoode Hall Law School, Class of 2004) is gratefully acknowledged.
} 


\section{Introduction}

As the recent Canadian movie "The Corporation" documents, the corporation has [2]

to a large extent replaced the Crown and religion as the institution that governs the lives of citizens worldwide. While historically Crown priority for payment of debts was rooted in the theory that the "King could do no wrong" this principle is being abandoned. However, in Canada the world of bankruptcy has been largely unaffected by this change. This is the case despite the fact that globally in the context of financially-troubled corporations, the demise of the privileged position accorded to the Crown has paralleled bankruptcy reform around the world that has been driven by institutions such as the International Monetary Fund. Bankruptcy reform has seen an international move from liquidation-based bankruptcy regimes to regimes that encourage corporations to reorganize when possible. Increasingly, governments are recognizing that formal reorganization provisions are necessary to deal with the number and diversity of creditors of an insolvent [5]

corporate debtor. There is also a growing realization that in most economies, the value of a corporation comes from its human capital and goodwill, rather than its assets. Accordingly, in many instances the value of liquidating corporations has been reduced.

Crown priority originally arose as part of the royal perogative. At common law, where there was a conflict between a Crown debt and another debt, the Crown's 
debt was to be given preference, so long as both were of equal degree. In many instances in Canadian bankruptcy history, the royal prerogative has been taken one step further by way of statutory provisions and judicial interpretations that favour Crown debt, even when it is not of equal degree to other competing debts. In reliance on the principle that because the royal perogative arose by way of common law it can be limited by legislation, bankruptcy and insolvency legislation governing Crown priorities has displaced the royal perogative in Canada. In this context, there is a long and detailed history of other creditors attempting to push the Crown to surrender its privileged position in bankruptcy or reorganization.

Interestingly, while the royal perogative has English roots, having been originally used by the Crown to assert a superior right to fish, wrecks, treasure [8] trove, swans and precious metals, England is the most recent jurisdiction to have abolished Crown priority in bankruptcy, with a view to encouraging corporations to reorganize when possible. This paper makes the case that abolishing Crown priority in bankruptcy and reorganization in Canada is optimal given a revaluation of traditional normative claims surrounding Crown priority in the context of a bankruptcy system that favours reorganization when possible.

In describing the events leading up to the most recent period of bankruptcy reform in England, commentators have observed that there was a move away from professional dominance and that discussions of reform resulted in "passionate 
exchanges among a wide array of creditors, debtors and policy-makers." In making the case for the Canadian abolishment of Crown priority in bankruptcy, this paper aspires to contribute to moving the content of the Canadian debate in the field of bankruptcy and reorganization more generally, and Crown priority more specifically, in this direction. While this paper focuses on Canada, it engages in a normative assessment that may be useful for possible reforms to Crown priority in the United States and in other jurisdictions that, like Canada, have been influenced, not only by the English model, but also by the American bankruptcy and reorganization system.

The international move from liquidation to reorganization-based regimes provides Canada with an opportunity to rethink Crown priority by weighing traditional normative claims along a new scale, where reorganization ranks high. Part II of this paper describes and situates the Canadian corporate reorganization system and Crown priority within the larger bankruptcy and insolvency system in Canada. Part III sets out and assesses the normative claims for granting the Crown priority in the context of a system that favours reorganization over liquidation. This paper concludes by arguing based on this normative assessment that Crown priority should be abolished in Canada and a system that encourages the Crown to adopt a more "commercial" approach to reorganization that commences prior to the initiation of bankruptcy proceedings should be implemented. This proposal is putforward as a preferable alternative to the current Canadian reform proposals for continuing to limit director and officer liability for unpaid tax and at the same time creating Crown liens 
prioritylegislation to deal with Crown priority inside and outside of bankruptcy in the same way.

\section{Crown Priority in Bankruptcy and Reorganization in Canada}

\section{A. Canada's bankruptcy and reorganization system}

The Canadian bankruptcy and reorganization system operates on the consensus that when a corporation is liquidated, economic and social losses flow to all stakeholders including shareholders, creditors, employees, suppliers, customers, the Crown and other involuntary creditors. Accordingly, a major goal of Canada's bankruptcy and reorganization system is to encourage reorganization where the socialand economic value of a reorganized corporation to all stakeholders, not just creditors, is more valuable than the liquidated [12]

corporation. However, despite the national and international desire to facilitate reorganization, the Canadian Crown still retains priority status, ahead of secured lenders, for unremitted employee sourcedeductionsandfor amounts for which a third party garnishment order has been issued prior to the commencement of a bankruptcyor reorganization of a corporate debtor.

The current Canadian framework provides that an insolvent corporate debtor can either liquidate or reorganize under the Bankruptcy and Insolvency Act. If a company has more than five million dollars in debt it can make use of either the BIA to liquidate or reorganize or the Companies Creditors' Arrangements Act to reorganize. Canadian courts have interpreted the CCAA as having a broad 
remedial purpose withaview to givinga debtoranopportunity tofind awayout of financial difficulties short of bankruptcy, foreclosure or the seizure of assets [15]

through receivership proceedings. By way of refinancing through debt, equity or the sale of business as a going concern, the BIA and the CCAA allow the debtor to attempt to reorganize in a way that will enable it to meet the demands of its creditors.

Following three decades of limited use, in the mid-eighties, in response to the rigidity of the Canadian BIA and the requirement at the time that a debtor company must be bankrupt to reorganize, the CCAA re-emerged as a significant part of Canada's bankruptcy and reorganization framework. The Canadian judiciary and insolvency practitioners have used the inherent powers granted under the CCAA to the court to replicate many of the practices and powers found in the American Chapter 11, ${ }^{[16]}$ however, without the same set of codified procedures and practices found in Chapter 11.

In contrast to the more specific provisions found in the BIA, the CCAA is a short statute, with few guidelines, that provides a flexible framework and the court with a high degree of discretion. Because reorganizations under the BIA tend to be less expensive but more rigid in nature, a reorganization under the BIA is better suited for a small, less complicated proceeding. The CCAA, on the other hand, provides more flexibility, a more comprehensive stay of proceedings, and accordingly is better suited to complex, larger reorganizations, that cannot easily fit into the more restrictive provisions found in the BIA. 
Under both pieces of legislation, the debtor company continues to run its business for the purpose of restructuring and a stay of creditors'collection actions against the reorganizing debtor is provided for. In the case of the $B I A$, a trustee, who is usually an accountant, is chosen by the debtor and approved by the court to oversee the process and at the same time provide guidance to the corporate debtor. In a CCAA reorganization, a monitor, who is also often an accountant, and can be the debtor's former auditor, is appointed to fulfil a similar function. Both the trustee and the monitor are court officers.

The trustee in a BIA and the monitor in a CCAA work with the corporate debtor to file a proposal or plan of reorganization with the corporations' creditors that typically provides for paying off only a portion of the corporation's debts and/or paying the debts over a longer period of time. Both the trustee and monitor must report to the court and the creditors on the financial affairs of the company, the cause of financial difficulties and also provide creditors with a comparison of how they would fare in a liquidation versus a proposal. The trustee has a much more detailed set of statutory obligations and licensing requirements than the monitor. The creditors and the court must approve the proposalorplan of reorganization.

When a corporation attempts to reorganize, the Crown will typically be one of its major creditors. In many cases, the Crown will have claims for employee source deductions and goods and services tax (a value-added tax known as "GST"). The tension that persists between the rights of creditors, particularly secured creditors, and the rights of the Crown when a corporation is insolvent are magnified when a 
corporation is attempting to reorganize rather than liquidate. In order to successfully reorganize, the corporation needs to be able to address the repayment or rescheduling of these liabilities. At the same time, in order to address these issues, the corporation needs to have "breathing space," a respite from collectionactivities of its creditors.

The battle over Crown priority in the Canadian bankruptcy context has been fought in the context of expensive and lengthy litigation over technical interpretations of the legislative provisions, without a clear articulation of the competing policies at issue. Currently, a major review of Canada's bankruptcy and restructuring regime is under way. In November 2003, the Standing Senate Committee on Banking, Trade and Commerce released its report after months of consultation with various stakeholders. The Senate Report expressed the view that the costs of restructuring should be minimized to the extent that it is reasonably possible and so as to provide insolvent companies with the incentive to reorganize rather than become bankrupt where it is in the best interests of the stakeholders. ${ }^{[20]}$ Further, the Senate Report expressed the view that tax policy and legislation should not move the debtor company to choose between restructuring and liquidation. However, the Senate Report did not recommend the abolishment of Crown priority in bankruptcy or reorganization.

In contrast to the United States, which has statutory priority schemes in its bankruptcy legislation to deal with Crown claims for unpaid tax in a debtor's 
bankruptcy or reorganization, or England, which historically relied on preferred creditor status for unpaid taxes, Canada currently relies on the deemed trust and the Crown's garnishment powers as the two primary mechanisms for granting the Crown priority in bankruptcy proceedings. Generally, amounts due and owing to the Crown are unsecured claims in a bankruptcy or reorganization. However, the deemed trust and garnishment powers operate to givetheCrownanincreasedability to collect its liabilities.

The priority status of creditors under a BIA liquidation can be divided into three categories. First in priority are trust claimants, who are not creditors in the sense that they have claim to property that the debtor holds in trust for them. Second in priority are secured creditors who hold a valid lien, charge or security interest on the property of the debtor. Third, are unsecured creditors that can be divided into two categories, preferred creditors and ordinary unsecured creditors. Preferred creditors are given priority over other unsecured creditors and include landlords and employees up toa maximumamount. The remaining creditors are ordinary unsecured creditors, including those with judgments, and share equally in what is left of the distribution after all other claims have been satisfied.

Prior to 1992, Crown claims ranked above all other unsecured claims, as a preferred creditor, even if the Crown claim was of equal degree. The 1992 amendments limited this priority and did away with the Crown's status as a preferred creditor. In an effort to circumvent this low ranking priority, amendments were made to non-bankruptcy federal and provincial legislation 
that created statutory liens for unpaid amounts owing to the Crown, a deemed trust for amounts withheld by a debtor on behalf of the Crown but not remitted, and provided the Crown with a power to garnish accounts receivable owing to the debtor. Both technical and constitutional battles were fought on each of these provisions. The Supreme Court of Canada held that attempts in provincial legislation to circumvent the bankruptcy legislation were unconstitutional because the provincial legislation conflicted with federal legislation. ${ }^{[28]}$ Such provincial legislation is effective against other creditors outside of bankruptcy proceedings, however, on the commencement of a liquidation or reorganization, the bankruptcy legislation prevails.

Currentlaw provides that in a bankruptcy or reorganization, the Crown's claim ranks as an unsecured claim unless the Crown has registered a security interest under applicable provincial laws. Even if the Crown has registered such a security interest, it is subordinate to competing security interests in the collateral that were perfected before the Crown's registration and the Crown's security interest is valid only in respect of amounts owing at the time of registration and any interest that accrues subsequently. However, the deemed trust status of source deductions pursuant to federal tax, pension and unemployment insurance and their provincial equivalents for money withheld but not remitted to the government, persists in bankruptcy and reorganization. ${ }^{[30]}$ Further, a garnishment letter sent out prior to the commencement of bankruptcy or reorganization proceedings retains a priority status. 


\section{B. Deemed trust}

The deemed trust provisions found in the Canadian Income Tax Act are recognized in liquidation and reorganization only for amounts withheld from employees for federal and provincial equivalents for income taxes, unemployment insurance and employee contributions to the Canada Pension Plan. ${ }^{[33]}$ On the deemed trust theory, withholding taxes are granted priority over secured as well as unsecured claims in liquidation, except for pre-existing liens on real property.

It has been estimated that approximately $87 \%$ of personal taxes in Canada are collected by way of employers withholding remuneration paid to employees on account of the employee's tax for the year and remitting these amounts to the government in prescribed intervals. The Crown estimates that employee withholdings generate "most of the funds required for the federal government's own operations, but also the amounts redistributed through various social programs." ${ }^{[35]}$ The current status of the deemed trust for unremitted source deductions can be traced to the Supreme Court of Canada's decision ${ }^{[36]}$ in Royal Bank of Canada v. Sparrow Electric Corp., the 1998 amendments to the ITA and most recently, the Supreme Court of Canada's decision in First Vancouver Financev. Canada(MNR).

In Sparrow, both the Royal Bank of Canada and the Crown claimed an interest in the proceeds of the bankrupt corporation. The Royal Bank had a security interest in the inventory of the corporate debtor that was characterized as a fixed and specific 
charge over the inventory. The Crown claimed a deemed trust with respect to the debtor's unremitted source deductions. The Court held that since the inventory was subject to the Royal Bank's security interest before the unremitted source deductions gaverise toa deemed trustin favour of the Crown, the RoyalBank'ssecurity interest attached to the debtor's inventory in priority to the Crown's interest under the deemed trust. However, in reaching this conclusion the Court noted that the government was free to amend the ITA to strengthen the deemed trust provisions.

Accordingly, in 1998, retroactively to 1994, the ITA was amended to provide that the deemed trust provisions are applicable from "the time the amount was deducted or withheld," "notwithstanding any security interest in the amount so deducted or withheld" ${ }^{[00]}$ and include "property held by any secured creditor ... that but for a security interest would be property of the person." Most recently, in First Vancouver, the Supreme Court clarified that the deemed trust for unremitted source deductions applies to after-acquired property, and while the deemed trust does not continue to attach to property sold by the debtor the proceeds of the sale are "captured by the trust."

Deemed trustclaims maybe stayed under both the BIA and the CCAA. However, while the stay is in effect, the debtor company must maintain the payments to the Crown and if the debtor defaults in so doing, the stay order ceases to be in effect. $^{[42]}$ Within six months of a CCAA plan or a BIA proposal being sanctioned by the court, the deemed trust claims must be paid, unless the Crown 
consents to an alternative payment schedule.

\section{Garnishment powers}

A statutory garnishment or an "enhanced requirement to pay" to recover GST or income tax issued before the date of bankruptcy, the filing of a proposal or an intention to file a proposal under the BIA or the initial order in a CCAA create a property right for the Crown and the receivables to which the garnishment letter attaches are no longer part of the bankrupt's estate. This power has given rise to a small amount of litigation, but has not presented the range of technical or constitutional challenges that have arisen in relation to the deemed trust. However, this power can in certain instances enable the Crown to force a debtor into liquidation, prior to providing the debtor with an opportunity to attempt to reorganize. The Crown can proceed in this manner without providing the notice that a secured creditor, who holds similar powers, is required to provide prior to enforcing its security. This issue is exacerbated to the extent that Crown priority is eliminated in reorganization or bankruptcy and a clear and consistent set of guidelines is not followed or articulated by the Crown as to how it will use the garnishment power when reorganization of a debtor is a possibility. [45]

\section{An Assessment of Normative Claims}

\section{Relating to Crown Priority}

This section outlines and evaluates the recurrent normative claims that have been 
made for and against Crown priority in bankruptcy proceedings. Each category of claim is specifically considered in the context of the move from liquidation-based bankruptcy regimes to regimes that encourage reorganization. Assessing traditional normative claims surrounding Crown priority in the context of a reorganization, rather than a liquidation, provides a good opportunity to understand Crown priority within a whole system, with wider ranging consequences than those impacting the distribution of the limited funds available when a corporation is liquidated. That is, the context is broadened to one that considers the implications of Crown priority on multiple converging and diverging interests, where certain decisions with respect to values and objectives have already been made with a move towards a reorganization based rather than a liquidation-based corporate bankruptcy system.

As with reorganization rhetoric standing alone, none of the normative claims alone suggest retaining or abolishing Crown priority in Canada, however, taken together a powerful claim for abolishing Crown priority in Canada may be made. The revaluation of traditional normative claims in this part of the paper illustrate that if Crown priority is abolished the Crown will lose a source of direct revenue, but this loss will be matched by private sector gains, which will indirectly help the Crown. ${ }^{[46]}$ That is, the net loss to the Crown resulting from the abolishment of Crown priority is less than the value that will be created for a wide range of stakeholders by allowing firms to reorganize. For firms that are ultimately liquidated, the net loss to the Crown from the abolishment of Crown priority is less than the value that will flow to unsecured creditors in not 
incurring further claims that they will have limited ability to collect on.

A. Involuntary creditor

Creditors can be divided into those that voluntarily contract with the debtor and involuntary creditors who are placed in a debtor/creditor relationship unwillingly. The Crown, as an involuntary creditor, cannot screen potential debtors prior to extending credit, and is compelled to take all debtors, regardless of the level of their credit. ${ }^{[47]}$ Another type of involuntary creditor is the tort claimant. ${ }^{[48]}$ Within the category of contractual creditors, certain creditors because of an inequality of bargaining power with the debtor may look more like involuntary creditors than voluntary creditors. Such creditors include unpaid suppliers of the debtor. Unlike other creditors, involuntary creditors and weaker voluntary creditors may not have the ability to diversify their credit and/or negotiate for terms that take into account their debtor/creditor relationship.

Depending on the amount of power or influence it is believed that the Crown currently holds in Canadian society, one might think that the Crown is a rather unlikely member of this group of relatively powerless creditors. At the same time, the Crown does share the attribute of being an involuntary creditor. The Canadian response in the liquidation context historically was to insert certain safeguards in the bankruptcy system for involuntary creditors and voluntary weak creditors. However, recently this response has been met with hostility from the insolvency practitioner community with claims stemming primarily from the 
impact of such priority on the possibility for reorganizing.

Accordingly, the Crown's claim to priority status as an involuntary creditor may be refuted on the basis of recent bankruptcy and reorganization reform efforts in Canada that have rejected granting involuntary and voluntary weak creditors a special priority on the basis of the involuntary nature of their claims where the successful reorganization of corporations is at stake. For example, as between small suppliers and the Crown, small suppliers are harder hit by default of the debtor and are less able to prepare for the risk, yet Canada has moved in the direction of eliminating any priority status for such suppliers. Further, unlike other involuntary creditors, the Crown is in a position to adjust tax levels to account for the possibility of default. In addition, unlike other involuntary and voluntary weak creditors, but similar to an investor contemplating an investment portfolio, the Crown has a completely diversified portfolio of debtors, which many consider to be a rational method of maximizing the value of one's investments. This advantage may be sufficient to compensate for the Crown's inability to adjust individual risk premiums when the risk of default of one of its debtor's increases.

B. Other collection options and the integrity of the taxation system

A key reason for the Crown's uneasy fit in a group of involuntary or voluntary weak creditors is the fact that that the Crown is supported by a strong legislative taxation scheme and has an arsenal of other collection devices, not shared by all 
other creditors, available to it prior to the insolvency of the debtor corporation. These include the imposition of penalties, high interest rates and third party liability. Further, it is open to the Crown to improve its status by registering a security interest against the corporate debtor. An argument can also be made that the Crown may impose certain additional requirements on corporate debtors, such as requiring that source deductions or unremitted GST be kept in a separate trust account or that a security bond be posted.

In a system that grants Crown priority for unpaid taxes in bankruptcy, delinquent collection efforts may be rewarded. This is the case despite the fact that requirements, such as those imposed on directors, ensure that the Crown has regular reports on the corporation's tax payments, which may be more information than is provided to many of the corporation's other creditors. Further, in many instances other unsecured and involuntary creditors will have noway of knowing if the corporation has been delinquent in its collection efforts. These are the same creditors who will carry the largest part of the burden if the Crown is granted priorityin liquidation.

The Crown's most convincing response to the claim that it has a whole host of other collection options available to it and that the current process rewards its shirking of responsibility, is that what is ultimately at stake in assessing the Crown's claim for priorityin bankruptcyis theintegrity of the taxation system. The rhetoric that supports Crown priority as a method of ensuring integrity of Canada's taxation system reflects the American position and was adopted by the Supreme Court of Canada in Pigott Project Management Ltd. v. Land-Rock Resources 
$L t d$, holding that "no other system is so crucial to the overall collections procedure adopted by the Crown ... understandably, that conversion cannot be countenanced if the integrity of that system is not preserved."

It has been suggested that the American position on Crown priority can be distinguished from the British pattern on the basis of a persistent rhetoric surrounding the integrity of the taxation system. That is, because taxation in modern society relies on the integrity of the taxation system, if Crown priority was limited or removed in the bankruptcy context, tax compliance would cease to exist. ${ }^{[58]}$ A similar normative claim has been made in the Canadian context, however, it is not supported by the actual functioning of Canada's taxation system as it relates to financially troubled corporations. This is demonstrated by an examination of the Crown's policy on Crown priorities. The Canadian Crown is of the view that "since the Crown's priority results from legislation that is binding on third parties, the CCRA [Crown] is not obliged to monitor the person's business, to issue forms or claims, or to register or publish notice of its priority rights" ${ }^{[59]}$ Further, "a creditor who is trying to decide whether to seize and sell a person's property in which the creditor has a secured interest, or thinking about appointing a receiver to recover the debt, cannot get any information about any amounts that the person may owe under a deemed trust unless the person gives the CCRA written authorization to disclose such information. However, once the creditor begins official proceedings to recover the secured amount, the CCRA can communicate the details of any deemed 
trust claim that it may have." This policy clearly does not comport with the Crown's claim that what is at stake in maintaining Crown priority is the integrity of Canada's taxation system.

When the goal of reorganization is inserted in the discussion surrounding the integrity of the taxation system, a persuasive argument may be made that a taxation system that does not exhibit all signs of integrity assists a financiallytroubled corporation in reorganizing by providing the corporation with time and money in the form of unpaid taxes. However, when the entire reorganization process is viewed as a whole this may not be the case. The higher the Crown's priority in a reorganization, the less likely that other stakeholders, such as unsecured creditors and certain secured creditors, will take an interest in the process, thereby negatively impacting the possibility of a successful reorganization.

The normative claim in favour of maintaining the integrity of the tax system favours abolishing Crown priority when viewed in the context of the interests and roles played by all stakeholders in reorganization. However, the Crown's current collection policies suggest the need for reform efforts to ensure that the goals of preserving the integrity of the taxation system while also encouraging reorganization are met in the pre-bankruptcy or reorganization context.

C. Protection of the public purse (or the general public)

Related to the rhetoricin favour of maintaining the integrity of the taxation system, the rhetoric in favour of allowing corporations to reorganize rather than liquidate 
is often centred on the public interest in retaining jobs, stability and community among other goals. However, in the context of Crown priority this claim is challenged by the view that it may be that the benefits to the smaller number of corporate stakeholders in allowing the corporation to reorganize are diminished by the impact of unpaid Crown debts on the public more generally. To that extent, the policy arguments centre on notions of property ownership and unjust enrichment. That is, the tax arrears are amounts that never belonged to the debtor and should not be used to reorganize the debtor or provide a windfall to the corporate debtor's other creditors.

Standing against this claim is the fact that corporate debtors cannot readjust the amount of credit owing to the Crown and transfer the risk of non-payment to the Crown because it is a "cheaper"creditor. The amount of tax owing is a legal requirement that cannot be adjusted beyond a maximum amount at the debtor's discretion. ${ }^{[62]}$ At the same time, in most instances, if the corporation is not able to reorganize, the public purse will be harmed by the very limited recovery on Crown debts. ${ }^{[63]}$ There is also the danger that if the Crown is granted too much priority with a view to protecting the public purse, Canada's bankruptcy and restructuring regime will not be the collective governance mechanism that it was intended to be, but rather a tax collection device. Further, the loss to the public purse may be proportionally minimal compared to the loss to other creditors and to the extent that other creditors are able to continue as taxpayers after the debtor corporation's reorganization, the Crown can continue to collect tax from them. 
It may be that in order to achieve the objective of reorganizing insolvent corporations, the losses should be born by the general public, not just those who were in a debtor/creditor relationship with the debtor.

Even within the Crown, more than simply tax authorities are implicated in the insolvency of a corporation. A A successful reorganization, may not only limit the extent of loss to the Crown for unpaid corporate taxes, but also the losses to other federal, provincial, and local governments with diverse economic interests in a corporation's reorganization. Ultimately, the quality of neighbourhoods, communities, the environment and retirement may be at stake in decisions as to whether to protect the public purse by abolishingor granting Crown priority.

Interestingly, the Senate has recently endorsed a view that would interfere with the public purse at the urging of the insolvency practitioner community on the basis of technical amendments to Crown priority. Currently, insolvent corporate debtors can convert debt into distressed preferred shares, which are accorded special treatment under the ITA, but that are costly to create. The benefit of such preferred shares is that they provide a low cost means of financing a restructuring at the expense of the public purse. The Senaterecommended amendments to the ITA that would dispense with the current procedures and provide that distress preferred share treatment for tax purposes be afforded to qualifying debt, for a specified period of time, by filing a notice of election. ${ }^{[68]}$ Further, Senate dealt with the current difference in tax treatment as between a debtor that reorganizes and a debtor 
that sells the business as a going concern. The Senate recommended that as is the case in a liquidation and purchase, a debtor should be able to elect to use fresh start accounting for tax purposes in a reorganization, with tax obligations relating to the period prior to the date of bankruptcy addressed as pre-filing claims. There does not appear to be a principled reason for a "back-door" approach to encroaching on the public purse, where the rhetoric that the Crown asserts in favour of retaining Crown priority rests on an interest in preserving the public purse.

\section{Bankruptcy as a collective process}

Similar to the policy in favour of including secured creditors in a bankruptcy proceeding, if the Crown is able to "pull the plug" in the same way that a secured creditor is able to realize on the oven of a reorganizing pizza parlour, a reorganization will be thwarted. ${ }^{[71]}$ As discussed in Part II, unlike secured creditors who are required to provide notice to the debtor prior to enforcing on their security, the Crown is not required to provide the debtor with notice prior to issuing a garnishment order. Accordingly, if Crown priority is abolished, garnishment orders may be issued with increased speed and frequency and a debtor may not have as long of a period to extend its operations in insolvency by making use of funds owing to the Crown.

It does not automatically flow from the implications of Crown collection mechanisms on the collective bankruptcy process that the Crown should continue to hold a priority status. Following the English approach, this claim supports the 
establishment of a better working relationship between the Crown, other creditors and debtors with the goal of full contribution to a system that favours reorganization. Such an approach necessitates an understanding that not all corporations should be reorganized.

UpuntilSeptember 2003, the Crown in England had been criticized forinsisting on $100 \%$ payment in order to approve proposals under the corporate voluntary arrangement ("CVA") and for taking significant periods of time to approve proposals. These problems were in part due to the lack of integration among departments and staffing problems, thereby frustrating proposals that unsecured creditors would otherwise agree to. ${ }^{[73]}$ It was recommended in the course of the 1999 consultations held by the Insolvency Service that the Crown develop a more commercial approach to CVAs so that proposals that were less than $100 \%$ would be accepted if it was held that the CVA would offer a superior return in the long run.

On the basis of these views, the taxing authorities in England established a Voluntary Arrangements Service, which had the mandate of working "to help its customers, to work collaboratively with the private sector and other government departments and to make a full contribution to business rescue by supporting viable businesses through periods of temporary difficulty." ${ }^{[75]}$ The Voluntary Arrangements Service published criteria for assessing the acceptability of proposals.

Even without the development of a Canadian equivalent to the British Voluntary 
Arrangements Service, the abolishment of Crown priority will provide the Crown with the incentive to support reorganizations given its low priority should the corporation ultimately liquidate. Further, to the extent that the current system provides debtors with a longer period of time to recover, as the Crown is less likely to the monitor its payment of taxes, the abolishment of Crown priority would place a corresponding incentive on secured creditors to monitor, albeit with less information. Ultimately, even if the result in such a system is that the Crown or secured creditors in certain instances will attempt to liquidate debtors more quickly, there may be a corresponding benefit to other stakeholders, such as unsecured suppliers, when the debtor is not be able to increase an unsecured debt that it will not be able to pay.

Canada has not adopted a blanket policy in favour of reorganization, but rather a policy in favour of reorganization when it is in the best interests of all stakeholders, including the Crown. Professor Sarra adopts this perspective in asserting, "when the firm is economically inefficient and change in governance practice will not remedy it's financial distress, the best outcome may be to liquidate and release the capital to higher value uses."

E. Effect on availability of credit

Secured lenders and the lawyers that represent them have repeatedly suggested that they will cease to lend funds to corporations or will do so only at a higher rate of interest unless the extent of the Crown's priority is clarified. For example, as one prominent Canadian lawyer, asserts: "Rather than increase its monitoring to ensure 
that source deductions are paid on a timely basis, Revenue Canada has shifted the burden of its monitoring to secured lenders, who may or may not have the ability to monitor the borrower's compliance with its duties to remit source deductions. This approach places additional risk on lenders, and will undoubtedly be factored into lenders' advance rates, and lenders' costs of doing business in Canada."

The claim made by lenders is that despite expensive and lengthy litigation that hasfocused on the technical bounds of the provisions relating to Crown priority in a bankruptcy or reorganization, there is still a significant lack of clarity, and the goal of enhancing commercial accessibility to credit by minimizing uncertainty in the resolution of policy disputes has not been realized. Rather, a "seize mentality" persists, as does a "technical war" among creditors. On this basis, lenders need to closely monitor debtors, which in turn pushes up the cost of credit and results in higher interest rates. This impact has been born more by corporations that are labour intensive, versus capital intensive, and have a significant number of employees and accordingly are subject to the deemed trust for unpaid source deductions.

Workingagainst this claimis the lackofempirical data retained by the Crownon exactly how much they collect by way of the existing mechanisms in a bankruptcy or reorganization and the lack of data supporting the fact that with each court challenge credit becomes less and less accessible. Further, market conditions also dictate the supply of credit and may mitigate against higher lending costs associated with Crown priority status. 
Given the pervasive nature of a security interest taken by an operating lender, and the fact that in most cases if Crown priority is abolished the benefit would [81]

flow to secured creditors, a more powerful claim may be made in favour of abolishing Crown priority on account of the corporate debtor's creditors on the basis that the Crown is also a creditor of these creditors. Accordingly, the secured creditors' gain out of the abolishment of Crown priority and the possibility of a reorganized entity may offset the Crown's losses in the form of increased taxes. This claim is most evident in a consideration of the difference between operating lenders who are secured by inventory and accounts receivable of the debtor and are better able to protect against the risk of Crown priority in their lending practices, andterm lenders who are secured by fixed assets and are not in a position to protect against such risk. Roderick Wood and Rick Reeson provide an excellent illustration of the problem with the existing law that grants the Crown priority over term lenders: "A seller (SP) sells a piece of heavy equipment to a construction company under a secured instalment purchase agreement. There is $\$ 100,000$ left unpaid on the purchase price and credit charges. The construction company later experiences financial difficulties and fails to remit source deductions. It also fails to make any further instalment payments to SP. ${ }^{[82]}$ Pursuant to the ITA, the Crown has priority over SP to the heavy equipment despite the fact that SPhas not benefited from the construction company's failure to remit source deductions. 


\section{F. Creditor's bargain}

In The Logic and Limits of Bankruptcy Law, Thomas Jackson makes the case that based on the creditor's bargain, entitlements in bankruptcy should not differ from those outside of bankruptcy. A system that does not follow this premise will provide an incentive for creditors to push a debtor into bankruptcy in order to obtain the advantages available in bankruptcy and not outside of bankruptcy. Accordingly, a claim may be made that Canada's bankruptcy and reorganization system should not provide for separate Crown priority, but should instead maintain the priority status held by creditors of a solvent corporation. This is the position that was adopted in the German Bankruptcy Code of 1994 (Insolvenzordnung), which was implemented in 1999.

A proposal resembling Jackson's model was put forward in evidence given to the [86] Senate this past year. The proposal provided for the creation of a new statutory regime that provides a uniform system for governing Crown priority both insideand outside of a bankruptcy or reorganization. The Thiform system would provide for a requirement that the Crown registers a security interest in order to retain a priority status in a bankruptcy or reorganization, with an exception to the first-in-time rule for security interests on amounts currently covered by federal deemed trusts.

Among other critiques that this proposal, like Jackson's model, may be subject to, is that it is based on the premise that an insolvent corporation consists of nothing more than a pool of assets, without a residual potential. This is 
contrary to both the Canadian and the international move to bankruptcy systems that value ongoing business relationships and recognize the hardships that fall not just on creditors, but also on other stakeholders when a corporation is liquidated. In order to achieve this objective, where there is an entitlement outside of bankruptcy, in many instances it will be necessary to revalue this entitlement in bankruptcy or reorganization with a new priority scheme that reflects a society's valuation of reorganized entities over liquidated entities.

Where the Crown retains the same priority status inside and outside of liquidation, it will have little interest in continuing with a reorganization. To the extent that the Crown has no priority status in a bankruptcy its concern with receivinga share of the entity maycontribute to the Crown's desire to assist in the reorganization of the debtor and to prevent the piecemeal sale of the corporation's assets. Further, a review of Canadian legislative history in this area suggests that the adoption of Crown liens priority legislation would give rise to another wave of technical amendments and litigation, and would not contribute to thegoalofreorganization of insolvent corporations when possible.

\section{G. Director and officer liability}

Intimately connected with normative claims pertaining to Crown priority are the normative claims relating to director and officer liability for unpaid taxes. At the same time as abolishing Crown priority in Canada, it may be necessary to reconsider a move towards limiting director and officer liability for unpaid taxes. Such an approach is consistent with the overall Canadian and 
international move towards holding corporate gatekeepers more accountable in [88] light of recent corporate scandals. However, this approach was not adopted in the Senate's recommendations on Crown priority or director and officer liability.

Currently when a corporate debtor becomes insolvent or is in the vicinity of insolvency, the corporation's directors are exposed to personal liability for unpaid debts including Crown debts. However, based on the fact that insurance for director and officer liability that covers liability to the Crown is increasingly difficult and costly to obtain during the reorganization period, and the desire to recruit and retain good directors and officers, amendments were made to the BIA and the CCAA in 1997. In both a CCAA reorganization and BIA proposal, the ability of the Crown to collect unpaid taxes from directors and officers is weakened by the range of defences available to directors under tax legislation and the possibility of compromising claims as part of the reorganization. The 1997 amendments now make it possible for a CCAA plan or a BIA proposal to provide for the compromise of claims against directors where they are legally liable in their capacity as directors for the payment of such [89]

claims. Further, to facilitate such a compromise, the stay may extend to them with respect to these claims.

$$
\text { [90] }
$$

Most recently, the Senate Report, with aview to increasing the number of competent directors willing to continue with insolvent corporations, recommended augmenting the compromise mechanism in the BIA by 
providing for a generally applicable due diligence defence against personal liability for unpaid taxes for corporate directors. Interestingly, the Senate Report did not make a similar recommendation for the CCAA. In order to satisfy the due diligence defence that is available under most existing tax legislation, directors must demonstrate active involvement in ensuring compliance. This may include evidence that controls were established to account for withholdings of employees and remittances, requiring financial officers of the corporation to report regularly on the implementation of these controls, and obtaining regular confirmation that withholdings and remittances have in fact been made during all relevant periods. ${ }^{[92]}$ It is unclear whether an amendment to the BIA to provide for a generally applicable due diligence defence would require the same evidence as is required under existing tax legislation.

Justifications in favour of imposing personal liability to third parties on directors and officers of corporations are premised on their roles as gatekeepers and monitors as well as the desire not to externalize the costs of operating a corporation. These arguments are said to be strongest in the context of involuntarycreditors, such as the Crown. Further, the justifications for limiting personal liability with the goal of providing directors and officers with the opportunity and incentive to engage in justifiably risky behaviour on behalf of the corporation is limited in the taxation context. As a corporation approaches insolvency, this risky behaviour may include putting off payment of taxes. The Crown has made the claim that if Crown priority is 
abolished this will lead them to issue garnishment notices at a higher speed and in larger numbers, with the ultimate result of forcing corporations into bankruptcy at an earlier stage. ${ }^{[95]}$ However, if Crown priority is abolished and amechanismis putintoplaceto ensure the cooperation of theCrown prior to bankruptcy, the need for an incentive to entice directors and officers to engage in such risky behaviour in order to achieve the goal of reorganization of a corporation will not exist. Accordingly, the need to further limit director and officer liability beyond the existing defences found in tax legislation may not be necessary if Crown priority is abolished.

\section{Conclusion}

Internationally and in Canada, multiple and competing approaches to corporate insolvency have been converging around the goal of preserving viable corporate enterprises. While Canada is a beneficiary in part of British insolvencylaws, over time there have been adjustments and diversions from the British approach, influenced by both local conditions and international developments. The history of Crown priority in Canada's bankruptcy system is one of undue complication that has taken away from the goal of an effective reorganization process. The evaluation of the normative claims in Part III builds a convincing case for reverting to our British roots by following their lead and dispensing with Crown priority. However, in order to effectively implement this process, it will be necessary for the Crown to commit to a "commercial approach" to reorganization even before a corporation has entered formal bankruptcy 
proceedings. A model for this approach is the English Voluntary Arrangements Service that was implemented prior to the abolishment of Crown priority in that country.

To summarize, the proposals put forward in this paper call for the abolishment of Crown priority, the adoption of a commercial and cooperative approach to collection of debts by the Crown and a reconsideration of the move to limit director and officer liability for unpaid taxes. These proposals are consistent with the growing international recognition that insolvency systems do not serve simply to raise the efficiency level of local and international economies. Rather, such systems are necessary to affect a balance among social, economic and political interests. ${ }^{[97]}$ These factors favour not only formal reorganization mechanisms, but also the abolishment of Crown priority in bankruptcy.

This paper has not provided a systematic explanation of why given a normative assessment that favours abolishment of Crown priority in bankruptcy Crown priority persists in Canada. Professional dominance of groups involved in reform efforts who have fees at stake in future work emanating out of technical amendments to Crown priority and the prevailing ideology of a small, homogenous group of lawyers and accountants who represent creditors and debtor corporations in Canada are likely part of the answer to this important question. The quest for the answer to this question should be part of the ongoing research agenda on issues of bankruptcy and reorganization reform in Canada. 


\section{End Notes}

1. J. Abbott \& M. Achbar, "The Corporation", Documentary (Canada: Big Picture Media Corporation, 2003). The Corporation traces the birth of the corporation as a legal person through history and uses the diagnostic criteria of the World Health Organization to diagnose the modern day corporation as a psychopath. See also, J. Bakan, The Corporation: The Pathological Pursuits of Profit and Power (Toronto: Viking Canada, 2004).

2. This paper refers to the Crown as synonymous with the state. This paper refers in particular to Crown priority for unpaid corporate tax.

3. Law Reform Commission of British Columbia, Report on The Crown as Creditor: Priorities and Privileges (1982) at 39 .

4. See Legal Dept., International Monetary Fund, Orderly \& Effective Insolvency Procedural Princtiples: Key Issues (1999).

5. Ibid.

6. Law Reform Commission of British Columbia, supra note 3 at 7 .

7. The Magna Carta stated, "The King's debtor dying, the King shall be paid first." Magna Carta (confirmed version), 9 Henr. III, 1225, 3 C.18 as cited in Tasse' Report at 122. See Canada, Study Committee on Bankruptcy and Insolvency Legislation, Bankruptcy and Insolvency: Report of the Study Committee on Bankruptcy and Insolvency Legislation (Ottawa: Queen's Printer, 1970) ("Tasse' Report").

8. Law Reform Commission of British Columbia, supra note 3 at 7 .

9. Carruthers \& Halliday, infra note 10 at 74 , define professional dominance as the degree of influence professions can have when professions (i) attain exclusive technical authority. That is, professions can convince policymakers that particular issues be the domain of private experts; (ii) convert substantive policy issues into technical issues that should not trouble public interest groups; (iii) persuade political bodies that expert recommendations embody central cultural values; (iv) become depended upon due to the weakness of the state, for example because the state has limited resources; and (v) have

great credibility, credentials and capacity for political mobilization. This paper does not purport to provide an investigation of professional dominance.

10.B. G. Carruthers \& T. C. Halliday, Rescuing Business:The Making of Corporate Bankruptcy Law in England and the United States (Clarendon Press: Oxford, 1998) at 194.

11. See Proceedings of the Standing Senate Committee on Banking, Trade and Commerce, Issue 22 (Ottawa: May 29, 2003); Senate Report, infra note 19 at Chapter 5, Section E.

12. This view was expressed as early as the 1986 Colter Report at 49. See Report of the Advisory Committee on Bankruptcy and Insolvency: Proposed Bankruptcy Act Amendments, (Ottawa: Ministry of Consumer and Corporate Affairs, 1986) ("Colter Report").

13. 13. R.S.C. 1985 , c. B-3 ("BIA").

14. R.S.C. 1985, c. C-36 (“CCAA"). The CCAA is Canada's only piece of bankruptcy legislation dedicated entirely to the reorganization of insolvent corporations

15. $\quad$ See Re Lehndorff General Partner Ltd (1993), 17 C.B.R. (3d) 24 (Ont. Ct.) (Gen. Div.).

16. U.S. Bankruptcy Code, 11 U.S.C., ch. 11 ("Chapter 11").

17. Section 11, CCAA.

18. This is the third major review since the Tasse Report, supra note 7 , over 30 years ago.

19. Canada, Report of the Standing Senate Committee on Banking, Trade and Commerce, Debtors and Creditors Sharing the Burden: A Review of the Bankruptcy and Insolvency Legislation and the Companies' Creditors Arrangement Act (Ottawa: November 2003) ("Senate Report").

20. Ibid. at 158 .

21. Ibid. at 157.

22. While Canada's bankruptcy and reorganization laws were originally based on English law, Canada's reorganization regime has been modelled in part on the American Chapter 11. The American bankruptcy and reorganization regime provides two primary mechanisms for either reorganizing 
or liquidating a corporation. Unlike Canada, both fall under one piece of legislation and both are available to individuals and corporations, without prescribed debt levels for entry. U.S. Bankruptcy Code, 11 U.S.C., ch. 7 ("Chapter 7"), provides for the liquidation or sale as a going concern of a corporation, and Chapter 11, provides for the reorganization of a corporation.

The Canadian position on Crown priority in a reorganization can be described as a "milder" version of the American position, which requires that certain tax debts be scheduled for payment in full before a court can confirm a Chapter 11 reorganization plan. See 11 U.S.C. 1129(a)(9)(c)(1988). Taxes given this treatment are listed in 11 U.S.C. 507(a)(7)(1988).

As is the case in Canada, in liquidation, under Chapter 7, priority tax claims must be paid ahead of most other unsecured debts. See 11 U.S.C. 507(a)(7)(1988). In addition, prior to a corporation's bankruptcy or reorganization, it is open to the Crown to take out a lien on a corporation's property if taxes are unpaid. See 11 U.S.C. 547(c)(6)(1988).

23. In broad terms, the order of payment in a liquidation in England is first for the costs and expenses of insolvency, second for fixed charges, third for preferential creditors, and fourth for floating charge-holders. What remains is divided among unsecured creditors.

24. For an excellent and brief description of secured financing in the Canadian common-law provinces and under Canadian federal law see American Law Institute, Transnational Insolvency: Cooperation Among the NAFTA Countries: International Statement of Canadian Bankruptcy Law (2003) at 129.

25. Section 136(1), BIA.

26. Bankruptcy Act, R.S.C., ch. B-3, section 136(1)(h), 136(1)(j).

27. Efforts to circumvent the Crown's relatively low status occurred prior to 1992. See for example British Columbia v. Henfrey Samson Belair Ltd., 59 D.L.R. (4th) 726, [1989] 5 W.W.R. 577, [1989] 2 S.C.R. 24. A full history and explanation of the Crown's current priority status is outside of the scope of this paper, which seeks to set out and assess the normative debates on Crown priority within the existing goals of Canadian and international bankruptcy and reorganization systems.

28. See for example, Deputy Minister of Revenue (Quebec) v. Rainville, [1980] 1 S.C.R. 35, Deloitte Haskins and Sells Ltd. v. Worker's Compensation Board, [1985] 1 S.C.R. 785 and Federal Business Dev. Bank v. Comm'n dee la sante et de la securite du travail, et al., [1988] 1 S.C.R. 1061.

29. See sections 86 and 87 , BIA.

30. Section 67(3), BIA.

31. See subsections 317(1), (2), (3) of the ExciseTax Act R.S.C. 1985, c. E-15 ("ETA") and section 224(1.2) of the Income Tax Act R.S.C. 1985, c. 1. ("ITA").

32. 32. R.S.C. 1985 c. 1 ("ITA").

33. The deemed trust for GST under the ETA is deemed ineffective when a corporation commences BIA proceedings. The issue of whether the deemed trust for GST under the ETA persists under the CCAA has dominated the recent jurisprudence on Crown priority coming out of the Canadian lower courts. Section 222 of the ETA deems GST collected to be held in trust, notwithstanding any other federal legislation except the BIA. However, subsection 18.3(1) of the CCAA provides, "notwithstanding any provision in federal .. . legislation that has the effect of deeming property to be held in trust for Her Majesty, property of a debtor company shall not be regarded as held in trust for Her Majesty unless it would be so regarded in the absence of that statutory provision." The two decisions on this issue that favoured the Crown came out of Alberta, and Justice Chadwick of the Ontario Superior Court of Justice rendered the third that limited Crown priority. See Re Solid Resources Ltd, [2003] 40 C.B.R. (4th) 219 (Alta. Q.B.), Re Gauntlet Energy Corp., [2003] A.J. No. 1504 and Re Ottawa Senators Hockey Club Corp., [2003] O.J. No. 5201. Leave to appeal was sought by the Crown in Re Ottawa Senators Hockey Club Corp. on January 9, 2004.

34. M. Bridge et al., "Formalism, Functionalism, and Understanding the Law of Secured Transactions" (1999) 44 McGill L.J. 567.

35. Canada Customs and Revenue Agency, "Deemed Trust-A Responsible Application Policy" (CCRA, Accounts Receivable Division Publications, 2001-01, March 7, 2002) as cited in J. S. Ziegel et al., Canadian Bankruptcy and Insolvency Law: Cases, Text and Materials (Toronto: Edmond Montgomery Publications Ltd., 2003) at 369 (“Ziegel et al.”).

36. This section does not provide a detailed technical analysis of the legislation or the decisions. For a more technical discussion see D. Winters \& N. Arnold, "Crown Priorities: The Supreme Court of Canada 
Trilogy" (1998) 15:2 National Insolvency Review; D. Winters, "The Continuing Evolution of the Deemed Trust: The Case of First Vancouver Finance" (2002) 14:6 Commercial Insolvency Reporter; S. J. Weisz and L. Rogers, "The Current Status of the Crown's Super Priority Interests in Insolvencies" (2000) 15:4 National Creditor Debtor Review; D. S. Grieve, "Post Sparrow Legislation" (1999) 12:2 Commercial Insolvency Reporter; D. Winters, "Priorities of Canada Customs \& Revenue Agency in an Insolvency" (2000) Insolvency Institute of Canada; and R. J. Wood \& R. T.G. Reeson, "The Continuing Saga of the Statutory Deemed Trust: Royal Bank v. Tuxedo Transportation Ltd." (2000) B.F.L.R.

37. (1997), 143 DLR (4th) 385 (SCC) ("Sparrow”).

38. (2002), 212 DLR (4th) 615 (SCC) ("FirstVancouver").

39. Section 227(4.1), ITA.

40. Section 227(4), ITA. 41.

41. Section $227(4.1)$, ITA.

42. Further, if a secured creditor holding security on property that could be claimed by the Crown in exercising its rights under s. 224(1.2) of the ITA, or other federal or provincial legislation, e.g. a bank holding a general assignment of book debts, is or becomes entitled to realize on its security, the stay is also terminated: s. $11.4(2)(\mathrm{b}), C C A A$.

43. Section 18.2(1), CCAA.

44. See subsections 317 (1), (2) and (3) of the ETA and section 224(1.2) of the ITA. The British Columbia Supreme Court in Re Canoe Cove Manufacturing, [1994] 6 W.W.R. 598 (B.C. S.C.) ("Canoe Cove") and the Federal Court of Appeal in Wa-Bowden Real Estate Reports Ltd., [1998] G.S.T.C. 46 ("Wa-Bowden") respectively held that garnishment under subsection 317 (3) of the ETA, before the date of bankruptcy, constitutes a property claim equal to the amount owed by the garnishee to the bankrupt. Wa-Bowden also held that the stay of proceedings under section 69.3 of the BIA does not apply by operation of subsection 317 (3) of the ETA when a garnishment is issued before the date of bankruptcy. The reasoning and result in the Canoe Cove and Wa-Bowden decisions have not been challenged by subsequent decisions. Also see Bank of Montreal v. Canada (Attorney General) (2003), 66 O.R. (3d) 161 (C.A.), holding that where a garnishment letter is received by creditors of the tax debtor prior to the tax debtor's assignment into bankruptcy but remitted after the assignment, the Crown has priority over the tax debtor's secured creditors.

45. The author thanks Diane Winters, Senior Counsel Department of Justice, for highlighting to her the extent and importance of this issue.

46. This appears to be the conclusion that was reached in the British context following a normative assessment. At the same time as abolishing Crown priority, the amendments to the Enterprise Act 2002 c. 40 that came into force in September 2003, set out a hierarchy of objectives in the new administrative procedure, the primary one being to rescue the company as a going concern. Prior to the 2003 amendments, in a liquidation, the Crown was given preferential status for Value Added Tax, Income Tax and National Insurance contributions Preferential creditors in England receive, on average, $96 \%$ of the amount owing to them in liquidation, while unsecured creditors receive, on average, 33\% of the amount owing to them. (Insolvency Service, Regulatory Impact Assessment for Insolvency Provisions in Enterprise Act 2002, at para. 5.30). It is estimated that the Crown recovers 90 million pounds per year preferentially in all insolvencies and that this amount would drop to 20 million pounds each year as a result of the 2003 amendments that have moved the Crown from a preferential creditor to an unsecured creditor. (Insolvency Service, Regulatory ImpactAssessment for Insolvency Provisions in Enterprise Act 2002, at para. 5.29).

47. Carruthers \& Halliday, supra note 10 at 225.

48. See K. Davis, "Priority of Crown Claims in Insolvency: Royal Bank of Canada v. Sparrow Electric Corp. and Its Aftermath" (1997) 29:1 Can. Bus. L. J. 145. Professor Davis asserts that unlike tort claimants, concerns of risk aversion, deterrence and individual justice do not flow from limiting Crown priority.

49. Doubt has been expressed within the Canadian context as to the special status of suppliers. In particular, claims have been made that suppliers could deal with their inequality of bargaining power by obtaining credit information on the firms they deal with from widely available credit rating services, obtaining insurance, or by selling their receivables to a factoring company. See K. 
Davis \& J. Ziegel, "Assessing the Economic Impact of a New Priority Scheme for Unpaid Wage Earners and Suppliers of Goods and Services" (Prepared for Industry Canada: Corporate Law Directorate, April 20, 1998).

50. That is, the Crown is a "non-adjusting creditor." See L. Ayre Bebchuk and J. M. Fried, "The Uneasy Case for the Priority of Secured Claims in Bankruptcy: Further Thoughts and a Reply to the Critics" (1997), 82 Cornell Law Review 1279 at 1288-99 as cited in Ziegel et al., supra note 35 at 351.

51. The involuntary creditor argument has been made consistently in Canada. For example see Law Reform Commission of British Columbia, supra note 3 at 24.

52. See subsections 136 and 81.1, BIA. The Senate Report has recommended abolishing this provision that enables suppliers to repossess their goods within 30 days after delivery on the view that given the archaic requirements imposed in this section, it has not functioned well and further that it reduces the money available for distribution to all creditors and it gives the supplier a right that it could have had it negotiated for this in its contract or took security. See Senate Report, supra note 19 at 108 .

53. V. Finch, Corporate Insolvency Law: Perspectives and Principles (Cambridge: Cambridge University Press, 2002) at 427.

54. R.A. Lopez-Ibor \& J. Artes-Caseslles, "Bankruptcy Proceedings and Government: Should Bankruptcy Law Grant Privileges to the Treasury" (2003) 9 German Working Papers in Law and Economics at 11 .

55. Ibid.

56. 56. (1996), 38 Alta. L.R. (3d).

57. Ibid. at 12 .

58. Carruthers \& Halliday, supra note 10, at 241.

59. Canada Customs and Revenue Agency, supra note 35 and accompanying text.

60. Ibid.

61. D. R. M. Jackson, "Forced Collectivization CCRA Style? Creditors Respond to the Latest Source Priority" (2002) 17:1 National Creditor Debtor Review at 9

62. R.A. Lopez-Ibor \& J. Artes-Caseslles, supra note 54 at 11.

63. See Tassé Report, supra note 7 at 122, n. 46: To measure the loss of revenue to the government due to the abolition of Crown priority in a given year, it would be necessary to ascertain the total dividends paid to the government in a given year and then deduct from this the sum it would have received as an ordinary creditor. One would, however, have to take into account the fact that due to a smaller loss, the other creditors would have to pay higher income tax. Lastly, one must consider the possibility that the elimination of the priority would improve the bankruptcy administration by increasing the chances of a better dividend for the ordinary creditors and by encouraging them to better look after their own interests.

64. See G. Triantis, "The Careful Use of Comparative Law Data: the Case of Corporate Insolvency Systems" (1997) 17 N.Y.L.Sch.J.Int' \&Comp.L. 193 at 205 warning that this is the danger in transplanting the reorganization rules and institutions from the U.S. to emerging countries. This is not to suggest that Canada is an emerging country.

65. The Tasse Report, supra note 7, took this perspective at 123: It could be argued that the government should rank after ordinary creditors, as the public treasury is, in fact, in a better position than anyone to bear the inevitable losses. The government can, in effect, divide the burden of tax left unpaid by the bankrupt among all the taxpaying public. It would be more logical for the government to do this, than to take advantage of the bankruptcy of an insolvent, taxpayer to reimburse itself, at the expense of the creditors who have already suffered losses. Certainly, there can be no rational explanation for the government to attempt to obtain payment of the tax due by a bankrupt from his creditors. Such a proposition offends one's sense of natural justice.

The Colter Report, supra note 12, held at 79 that "the burden of tax left unpaid should be divided among all the tax-paying public rather than borne by the creditors, who have already suffered losses." 
66. J. Sarra, Creditor Rights and the Public Interest: Restructuring Insolvent Corporations (Toronto: University of Toronto Press, 2003) at 90.

67. Ibid. at $56-112$.

68. Senate Report, supra note 19 at 158.

69. Ibid.

70. Ibid.

71. The Colter Report, supra note 12, recognized at 77 that the Crown priority frequently stands as a barrier to effective reorganization.

72. A corporation can also affect a reorganization under section 425 of the CompaniesAct1985. However, such schemes of arrangement have rarely been used because of complications in identifying classes of creditors, the requirements of a majority in number and $75 \%$ approvals and the length and inflexibility of the process. See Finch, supra note 53 at 329.

73. See Finch supra note 53 at 342.

74. As noted in Finch, supra note 53 at 342-43.

75. D. Ellis, "Inland Revenue and Business Rescue" (2001) Recovery (September) at 18-19 as cited in Finch, supra note 53 at 343.

76. See www.inlandrevenue.gov.uk.

\section{Our Aim}

We want to contribute to the development of the rescue culture by supporting viable businesses experiencing temporary financial difficulties. This support will be directed at providing the optimum return on existing debt so that loss to the Crown is kept to a minimum, and encouraging proposes to meet their future statutory obligations on time. We believe that supporting businesses that identified and eliminated the causes of past difficulties will stimulate enterprise and ultimately provide greater revenue. We will support the closure of businesses (individual or corporate) that do not expect to become viable. A key test of viability will be the ability of a business to meet out of income all statutory liabilities as they fall due.

...

When Will We Seek To Modify AVoluntary Arrangement?

Ideally we should not need to modify the substance of a voluntary arrangement proposal very often because we expect the optimum offer to be put forward to creditors after due provision for necessary business expenses including all statutory liabilities as they fall due and (where applicable) reasonable private and domestic expenses we will discuss how we consider that the offer can be improved and then look to the purpose to change the proposal voluntarily. If the proposal is not improved voluntarily we will propose modifications to the substance of the offer. We may insist that all of these are approved before we agree to support the proposal. We may also need to make technical amendments to the proposal that will not affect the purpose's obligations under it, e.g. to define terms or clarify the role of the supervisor. We will discuss these with the insolvency practitioner who is acting.

77. Sarra, supra note 66 at 52 .

78. K. D. Kraft, "Revenue Canada Policy Statement on Deemed Trusts" (2000) 12:3 Commercial Insolvency Reporter.

79. This claim can be traced to the Tasse Report, supra note 7, which adopted the language of Professor J.A MacLachlan at 123:

.. . They strike the commercial community where it is weak by further impairing the financial condition of creditors who have had the misfortune of extending credit to the bankrupt... unless governments can stop proliferating taxes to the lavish largesse on politically favoured groups and to give public credit to those unworthy of private credit, bankruptcy may become just another device for paying official salaries.

80. Preliminary data were provided to the author by the Office of the Superintendent of Bankruptcy collected from a database of public records of 275 corporate bankruptcy cases, which were filed after September 30, 1997 and closed by October, 2001. These files were randomly selected and 
represent approximately $10 \%$ of the corporate files closed in this period. After the files were further reviewed, 131 of the 275 files remained. Out of these files only in 44 cases did the Crown recover amounts for source deductions. In these 44 files the rate of recovery by the Crown on the deemed trust for source deductions was $4.23 \%$. Out of the 131 files, 21 files had more than a zero amount in the category of total unsecured dividends. The mean amount recovered on such dividends was $\$ 14,927.65$ and the median amount was $\$ 3,319.56$.

81. The Colter Report, supra note 12, did not take this view at 78-9. The Committee expressed the view that unsecured creditors often do not take an active interest in the administration of a bankruptcy because all of the proceeds of any recovery will go to the Crown as a preferred creditor. They were of the view that once the Crown's preferred status was removed, unsecured creditors would have a greater incentive to involve themselves in the administration of bankrupt estates.

82. R. Wood \& R. Reeson, "The Continuing Saga of the Statutory Deemed Trust: Royal Bank v. Tuxedo Transportation Ltd." (1999-2000) 15 B.F.L.R. 515 at 528.

83. 83. Section 227(4.1).

84. Cambridge, MA: Harvard University Press, 1986.

85. Insolvenzordnung v.5. 10. 1994 (Bundesgesetzblatt, BGBI, IS2866).

86. See Canada, Proceedings of the Standing Senate Committee on Banking,Trade and Commerce (Ottawa: May 29, 2003); and Canada, Proceedings of the Standing Senate Committee on Banking, Trade and Commerce (Ottawa: October 1, 2003).

87. See R. C.C. Cumming, "An Approach to the Rationalization of Enforcement of Federal and Provincial Crown Claims (October 1999) (unpublished, prepared for Industry Canada: Corporate Law Policy Directorate) as cited in Ziegel etal., supra note 35 at 374.

88. P. Puri \& S. Ben-Ishai, "Proportionate Liability under the CBCA in the Context of Recent Corporate Governance Reform: Canadian Auditors in the Wrong Place at the Wrong Time?" (2003) 39 Can. Bus. L. J. 36.

89. Section 5.1, CCAA, with an exception in sections 5.1(2) and 5.1(3) for the proposition that a compromise against directors may not include claims that relate to contractual rights of one or more creditors or that are based on allegations of misrepresentations made by directors to creditors or of wrongful or oppressive conduct by directors or where the court declares that a claim shall not be compromised if it is satisfied that the compromise would not be fair and reasonable in the circumstances. A similar provision is found at section 50(13) of the BIA with an exception in section $50(14)$ of the $B I A$ for the compromise of claims against directors may not include claims that relate to contractual rights of one or more creditors arising from contracts with one or more directors or that are based on allegations of misrepresentation made by directors to creditors or of wrongful or oppressive conduct by directors.

90. Section 11.5, CCAA.

91. Senate Report, supra note 19 at 121.

92. See Canada Customs and Revenue Agency, IC89-2R-ERR Directors' Liability-Section 227.1 of the ITA and Section 323 of the Excise Tax Act (ERRATUM) (1997).

93. E.M. Iacobucci, "A Wise Decision? An Analysis of the Relationship Between Corporate Ownership Structure and Directors' and Officers' Liabilities" (2002) 36:3 Can. Bus. L.J. 337.

94. Ibid.

95. D. C. Tay \& O. Pasparakis, "The Compromise of Directors' Liability for GST" (2000) 13:2 Commercial Insolvency Reporter.

96. See supra Part III, Section D at 15.

97. See Legal Dept., International Monetary Fund, supra note 4. 